Portland State University

PDXScholar

2008

\title{
Milk Teeth and Jet Planes: Kin Relations in Families of Sri Lanka's Transnational Domestic Servants
}

Michele Ruth Gamburd

Portland State University, b5mg@pdx.edu

Follow this and additional works at: https://pdxscholar.library.pdx.edu/anth_fac

Part of the Social and Cultural Anthropology Commons

Let us know how access to this document benefits you.

\section{Citation Details}

Gamburd, Michele Ruth, "Milk Teeth and Jet Planes: Kin Relations in Families of Sri Lanka's Transnational Domestic Servants" (2008). Anthropology Faculty Publications and Presentations. 42.

https://pdxscholar.library.pdx.edu/anth_fac/42

This Post-Print is brought to you for free and open access. It has been accepted for inclusion in Anthropology Faculty Publications and Presentations by an authorized administrator of PDXScholar. Please contact us if we can make this document more accessible: pdxscholar@pdx.edu. 


\title{
Milk Teeth and Jet Planes: Kin Relations in Families of Sri Lanka’s Transnational Domestic Servants
}

Michele R. Gamburd

Portland State University

\begin{abstract}
This essay examines the confluence of local and global dynamics, exploring how transnational migration affects and is affected by gender roles, kinship relations, intergenerational obligations, and ideologies of parenthood. Journeying to the Middle East repeated on two-year labor contracts, many of Sri Lanka’s migrant housemaids leave behind their husbands and children. Women’s long-term absences reorganize and disrupt widely accepted gendered attributions of parenting roles, with fathers and female relatives taking over household tasks. Migrants say that economic difficulties prompt migration, and assess commitment to kin in financial terms. The government also benefits from remittances. Nevertheless, stakeholders (villagers, politicians, and the national media) worry about the social costs born by children. Drawing on interviews with the adult children of migrant mothers in four extended families in the Sri Lankan coastal village of Naeaegama, I examine the long-term effects of transnational labor migration on local households. I look into marital tensions between husbands and wives regarding domestic duties, and I consider emerging changes in intergenerational obligations. The case studies do not support media claims that children suffer abuse and neglect in their mothers' absence, but do in part support survey information on reduced education, shifting marriage patterns, and paternal alcohol consumption. This paper contributes to the debate on the intersection of globalization
\end{abstract}


and kinship studies, and explores the politics of representation at work in the discourse surrounding the social costs of migration.

Keywords: transnational migration, globalization, gender, kinship, parenthood, Sri Lanka.

\section{Introduction}

For over a quarter of a century, women from Sri Lanka have journeyed to the Middle East to work as domestic servants. ${ }^{1}$ Migration choices reflect stark financial conditions growing out of many years of economic liberalization. Spurred by the scarcity of jobs at home and the ample employment opportunities abroad, migrant women leave their families to join the households of strangers. Their work modifies the division of domestic labor in the family they leave behind and in the family they join. In Sri Lanka, fathers and female relatives take over child-care and other household tasks, and gender roles and kinship obligations between parents, children, and other relatives shift and change. These changes in gender and family structures, the most basic units of social organization, make many stakeholders anxious. Remittances sent home by migrant laborers provide much-needed cash for family use and supply welcome foreign currency to the Sri Lankan state. But while economically beneficial, migration decisions clearly have social and emotional costs - costs that local families, government officials, and the media discuss at length. Debates about how migration affects gender and kinship unfold with a great deal of hype and colorful rhetoric, performed within complicated political agendas.

Sung from the perspective of a migrant worker who has just left behind her husband and children to start a contract abroad, the popular song "Oceans Apart” tugs at the heartstrings and illustrates the social and emotional issues in question: 
I nursed and held you to my heart only yesterday;

Oh my precious ones! We're oceans apart today.

This truly is a palace, but it's alien and lonesome to me.

Is it a mountain of fire rising within me?

My hands are nimble, cooking a right royal meal.

My eyes are blurred, on my lips there's a salty feel.

Whether the hearth in my home is lit I do not know.

Wasn't your mother right there in the sweetest dream that you saw?

I hope the sun in the eastern kingdom will not be idle to rise.

Is there a big fuss when your father brushes your milk teeth?

I gaze and gaze at your picture where brilliant smiles sparkle.

For a fleeting moment the Sahara feels the soothing touch of a sprinkle.

Written and translated by Swarna Kanthi Rajapakse

In this song, a mother, torn from her children, adjusts to life in a foreign land where she cooks for her wealthy sponsors. She cries quietly, uncertain how her husband will cope at home with unfamiliar parenting tasks and household chores. In this article, I examine both fact and fiction in the high-voltage discourse surrounding the social costs of labor migration of Sri Lankan women to the Middle East. 


\section{Theoretical context}

For at least two decades, anthropologists have recognized the truism that one cannot elucidate local dynamics without reference to the global (Appadurai 1990; Kearney 1995). Cultural and economic processes at the international, national, and regional level reach into households all over the world, affecting arenas as diverse and as deeply meaningful as diet, death, and ritual traditions (Hoskins 2002; Phillips 2006; Wright 2001). The term "globalization" reflects the worldwide integration of economies and the pervasiveness of capitalist ideologies. As a result of global and national neo-liberal economic policies, poor families in developing nations find it difficult to make ends meet, and many have solved this problem by sending an adult (often a woman) to work abroad (Chang 2000; Harrison 1997; Parrenas 2001). This disrupts older patterns of family organization and puts understandings of gender roles and appropriate parenting into flux.

While one cannot understand the local without reference to the global, there is an equally important but perhaps less obvious reciprocal truth: one cannot fully understand global structures and processes without reference to the local. Ethnographic discussions of agency, decisionmaking, and cultural logic at the family, village, and city level make clear how local dynamics shape larger trends and patterns. Studies of transnational migration illustrate this claim vividly, examining the role of migrant subjectivity (Ong 1999), gender roles (Morokvasic, Erel, and Shinozaki 2003), and generational obligations (Cole and Durham 2007) in fashioning large-scale population movements. Labor flows from sending countries depend on family structures that facilitate migration (Magazine and Sanchez 2007), and demands for labor in host countries rely on cultural assumptions about the gender, race, religion, and other characteristics of the ideal worker (Longva 1997; Nagy 1998). Drawing on interview data gathered in the coastal village of 
Naeaegama, ${ }^{2}$ this essay examines the confluence of local and global dynamics, exploring how transnational migration affects and is affected by gender roles, kinship relations, generational obligations, and ideologies of parenthood.

To assess how migration affects and is affected by household structures and to unpack the politics of representation at work in the discourse surrounding the social costs of migration, a scholarly discussion of the family provides useful insights. Once considered a bastion of conservative practices, the family is now recognized as a social structure in constant flux, continually reacting to economic circumstances and political exigencies such as state policies, civil strife, international migration, and the global capitalist economy (Lynch 1999, 2007; Stacey 1990; Willis and Yeoh 2000). Family structure is thus much more a product of ongoing adjustments to changing circumstances than a "traditional" form of social organization (Kapadia 1993; de Munck 1996). Ideologies and, to a certain extent, structures might lag behind circumstances, but they are always responding to the present instead of merely reflecting the past. Behaviors of husbands, wives, parents, and children are shaped by cultural norms about how family members should treat each other. At the same time, ordinary people leading their ordinary lives also rework and reevaluate these norms (Ortner 2006).

Theorists see the family as the basic unit of social organization and cultural reproduction. The feminist anthropologists who led the 1980s renaissance in kinship studies caution against the uncritical acceptance of "folk knowledge" about what constitutes a "good" or "normal” family. Jane Collier and Sylvia Yanagisako (1987) suggest that scholars need to be especially wary of a series of dichotomies that often structure Euro-American commonsense assumptions about the division of labor within families. They suggest that anthropologists have often associated male roles with productive activities that take place in the public sphere, while associating female 
roles with reproductive activities that take place in the private or domestic sphere. Carla Freeman (2001) extends the critique of these persistent dichotomies to analyze recent theoretical work on globalization, suggesting that local and global also conjure up associations of femininity and masculinity. Some of these idealized dichotomies appear in Sri Lankan debates about migration - often because transnational domestic migrants challenge basic assumptions about gender and kinship by leaving their homes, traveling abroad, and working for wages in the public sphere. Anthropological insights warn against making faulty assumptions while also illuminating the power of gendered categories in the popular imagination.

A full consideration of migrant families requires analysis not only of gender and kinship but also of class. Poverty, which challenges families to meet their most basic needs, plays a major role in organizing family structures. Mary Weismantel points out the value of studying kinship "on the economic periphery" (1995:689). Anthropologists have considered how and why families engage in fosterage and child circulation for over thirty years, exemplified by Carol Stack’s groundbreaking work among poor African Americans in Chicago (1970). More recently, Melanie Nicholson (2006) contrasts the white, middle-class, American concept of exclusive, intensive motherhood in a nuclear family with the forms of motherhood more common in nonwhite, poor, Latin American, African American, and Hispanic families, where economic conditions necessitate that women share child-rearing responsibilities with others, preferably their kin. Despite detailed ethnography, class-, race- and gender-based assumptions about family abound. Evelyn Blackwood (2005:4-5) notes that many scholars continue to seek a "dominant patriarchal man” who heads a "heteronormative family," even in matrifocal or matrilineal contexts. When a parent plays a non-normative (non-middle-class) role, some people assume that the family is flawed or dysfunctional. Popular opinion and conservative rhetoric reflect similar 
views when blaming social problems on "abnormal” (non-white, working-class) family structures (Stacey 1997). This mindset erases questions of economic inequality and social justice by blaming problems on the "bad" families of the poor rather than examining how poverty nourishes the problems and shapes the kinship structure. Similar class dynamics appear in the Sri Lankan discourse surrounding the social costs of migration. I argue that we need to examine poverty as the background against which families make decisions about migration and reallocate domestic duties to those who remain behind.

In weighing economic benefits against social and emotional costs, poor migrant families often come to decisions that other members of their society question. The absence of a migrant parent creates what many view (and hence fear) as an "abnormal” family, particularly when the migrant is a mother (Parrenas 2005:38). Discussions center around the effects mothers' absence will have on the emotional and physical well being of their children. Although they take place all over the world, these debates are seemingly framed within middle-class Euro-American assumptions about intensive, exclusive mothering with an emphasis on abstract emotion (Lutz and Abu-Lughod 1990). But do such assumptions capture the beliefs of parents living under the threat of poverty? Anthropologists who study family dynamics skillfully portray the performative aspects of a parent's nurturing love, highlighting practices that make sense within the local context but strike the uninitiated as counterintuitive. For example, in northeastern Brazil Nancy Scheper-Hughes (1992:356) argues that high rates of child death due to "extreme poverty and exploitative female wage labor" create a political economic context in which a mother does not bond with her child until it seems clear the child will survive. And in South India, "Mothers deliberately spurned or mistreated their own children, forcing their own and their children's affection away from the closest blood bond” (Trawick 1990:103). This practice teaches children 
to be tough and emphasizes the importance of the joint family, a kinship strategy that mitigates situations of scarcity. These examples conclusively demonstrate that "mother love" is not a universal, pre-cultural state or sentiment. Instead, parenting practices emerge specific to particular contexts.

In Sri Lanka, parents in migrant families identified their primary obligation to their children as "caring” for their tangible, physical wellbeing. When I asked whether it was mothers or fathers who were best able to take care of the emotional needs of children, one couple dismissed my concerns as irrelevant. They speculated offhand that in the abstract it might be better for a woman to stay at home and care for her children, but declared that this had became a moot point in their own household due to economic hardship, the scarcity of jobs in Sri Lanka, and the opportunities for women to work abroad as domestic servants. When I asked another returned migrant about how her prolonged absence had affected her four sons, she dramatically asserted, "If I had not gone abroad, my family would have starved to death long ago. The trees would have grown tall over our graves by now!” Without her wages, she argued, her family would have fallen into severe poverty; with her wages, the family could afford everyday needs such as food and education, and could save some money to buy land and build a house. This woman and many others felt that despite the logistical and emotional difficulties inherent in migration, working abroad ensured everyday survival and a brighter future for their families. Financial necessity trumped emotional concerns.

Despite the pragmatic approach taken by many migrant families, the rethinking of gender roles and normative family structures is not without tensions and conflicts at the family and state levels. As I discuss below, while acknowledging transnational domestic servants’ important contribution to the national economy, many Sri Lankan critics deplore the social costs born by 
migrants' families. Around the world, female labor migration sparks often-heated rhetoric on hot-button issues such as women's safety, national pride, proper gender roles, and the decline of family solidarity (Decena, Shedlin, and Martinez 2006). These debates reflect common patterns in how gender and nationality interact in a context of neoliberal global capitalism (Lynch 2002; Wright 2001). States have a tendency to blame mothers for problems that might more accurately be read as failures of the state itself to provide for the reproduction of society (Ross 1995:411; Ehrenreich and Hochschild 2002:8-9). Emphasizing the drawbacks of female migration, some Sri Lankan politicians have called for its abolition. For example, early in 2007 the Sri Lankan government briefly considered banning the migration of women with children under the age of five (Rakesh 2007). Public outcry and economic realities at both the family and the national level made such a ban on migration impossible, but the anxieties about social costs persist.

In this essay, I investigate the long-term effects of migration on migrant women's families, and I explore the issues at stake in local discussions about gender and kinship. Drawing on interviews with the adult children of migrant mothers in four extended families, I examine how these young men and women conceptualize the effects of transnational labor migration on their households. I also consider how various stakeholders (villagers, politicians, and the national media) view the balance between production and breadwinning on the one hand and reproduction and nurturing on the other. I focus especially on cases where migration has reorganized and disrupted widely accepted gendered attributions of parenting roles. I look into marital tensions between husbands and wives regarding domestic duties, and I consider emerging changes in intergenerational obligations.

\section{The political economics of Sri Lankan labor migration}


Many idiosyncratic factors motivate migration, but all decisions take place against a country-wide economic and political background. Among the poorer segments of Sri Lanka’s population (25-40\% of the people), un- and underemployment are high, especially for women (Central Bank 2003:9; Institute of Policy Studies 2003:63-5; Ruwanpura 2000). Sri Lanka’s transnational domestic workers come disproportionately from the poorer segment of society. This labor stream reveals the inequalities inherent in the current global capitalist division of labor.

As oil flows out of the oil-producing countries of the Gulf, laborers from all over South, Southeast, and West Asia flow in. In 2005, over 660,000 Sri Lankan women worked as domestic servants in West Asia, particularly Saudi Arabia, Kuwait, Lebanon, and the United Arab Emirates (SLBFE 2006:58). Many of these international labor migrants, who represent roughly 13.5\% of Sri Lanka’s working age women, leave behind husbands and children when they travel abroad (SLBFE 2006:59). Sri Lankan “housemaids” working abroad often become the sole breadwinners for their families. ${ }^{3}$ Private remittances from contract workers in the Middle East amounted to over a billion U.S. dollars in 2005 and supported an estimated 20\% of the island's population of 19.5 million people (SLBFE 2006:88). A labor stream of this magnitude naturally has a profound impact on the economic and social wellbeing of families in Sri Lanka. ${ }^{4}$

Within this global and national context, I situate my field work in the Sinhala-Buddhist village of Naeaegama. For fifteen years, I have collected qualitative ethnographic data on labor migration from Sri Lanka to West Asia (Gamburd 2002, 2005). Located on Sri Lanka’s coast about fifty miles south of the capital, the village of Naeaegama covers about one square mile and had roughly 1,100 residents in 2004. Most people rented or owned small plots of land that could not support a family’s agricultural needs. In Naeaegama, as in much of the rest of Sri Lanka, 
available jobs were mostly poorly paid and temporary (Jayaweera et al., 2002:24). Local employment opportunities for men included work in the armed services or the tourism industry, civil service jobs, daily manual labor jobs, and self-employment as cinnamon peelers or makers and peddlers of coconut fiber brooms. Opportunities for women included making coconut fiber rope, teaching, and working in local garment factories. Most significantly, since the early 1980s, a large and ever-growing number of women from Naeaegama have gone to work abroad as housemaids (Gamburd 2000). Although transnational domestic workers earned only an average of SLR 10,000 (US\$100) a month while abroad, this was between two and five times what women could earn working in Sri Lanka, and equaled or exceeded the wages earned by most village men.

Economic necessity topped the list of motives when migrants talked about their choice to work in the Middle East. Women consistently asserted that families could not make ends meet on local salaries and saw migration to the Middle East as the only available economic alternative (Gamburd 1995). Family motives for migration usually included getting out of debt, buying land, and building a house. Women also stated that they hoped to support their family’s daily consumption needs, educate their children, and provide dowries for themselves (unmarried migrants) and their daughters (married migrants) (Gamburd 2003; Gunatillake \& Perera 1995:48, 55). Participants in the decision-making process (undergone repeatedly for migrants who return several times to the Gulf) weighed financial necessity and household improvements against separation, incursion of loans, and alternate arrangements for childcare (Gamburd 1998).

In February 2004, 88 Naeaegama residents had been or were then abroad. Current and returned migrants thus represented eight percent of the village population and 16 percent of the people of working age. Of the 174 village households, 73 (42 percent) had or had had at least one 
person abroad. Three-quarters of these migrants were female. Most Naeaegama women, like other Sri Lankan migrants, came from the 20-45 year age range, had six to nine years of schooling, were married and had two or more children, and had not otherwise worked outside the home (Eelens et al. 1992; Weerakoon 1998:102) Data from Naeaegama corroborate studies that suggest that each migrant woman supports an average of five members of her family (Jayaweera et al. 2002:1; Weerakoon's 1998:109). There were roughly 130 adult children of migrant women in Naeaegama. Some of them were in their early twenties, and their mothers had started going abroad in the early 1980s. In 2004, following up with families I have known since 1992, I interviewed a number of these adult children and their family members. Mine is not a systematic controlled study. ${ }^{5}$ Nevertheless, the interviews provide revealing data on decision-making strategies and family adjustments to migration.

\section{Stereotypes vs. scholarly studies}

Stories abound both in the local area and in the national media concerning the suffering of children whose mothers have gone abroad. Based on second- and third-hand information, many of these horror stories contain more rumor than fact. For example, some Naeaegama residents talked about the daughter of a poor couple in the area, saying that she used to arrive at school neatly dressed and do well with her letters. But after her mother went to the Middle East, the girl showed up with lice and began to do poorly in her studies. This local child clearly exemplified the worst social costs of labor migration. But no one who mentioned the girl to me had examined either her hair or her school books. She caught the village attention more as an icon than as an individual. As the story circulated, it lost context, nuance, and accountability. 
Similarly, the public discourse on the effects of transnational domestic workers' absences on their children often generalized and over-dramatized the dangers of migration. For example, in a parliamentary discussion, a politician reportedly suggested that, "In a large percentage of [migration] cases, the children get neglected” (Nakkavita and Jayamanne 2004:10, emphasis added). A high-ranking Sri Lankan politician stated: "The girls in most of these families are harassed and abused whilst the husbands and boys go astray. Most of them become addicted to alcohol and drugs” (Daily Mirror 2003:4, emphasis added). Such blanket statements glibly suggest that parents have "neglected" their children, overlooking the fact that mothers have often gone abroad to provide primary necessities such as food and shelter. The discourse blames mothers and fathers in migrant families for a number of poverty-related social ills, simultaneously eliding state responsibility for grim economic conditions such as unemployment and a lack of social services. Such stories and statements exaggerate and misrepresent the difficulties of families left behind.

Public discourse also lacks an accurate presentation of risks and a nuanced discussion of children’s needs at particular ages. Despite its discursive prominence, relatively little scholarly research has explored this topic. A study by Sri Lankan psychologist Gameela Samarasinghe reveals that migrant mothers rarely leave behind children younger than one year of age, and the primary caregivers for these children unanimously felt that they were fulfilling all the functions that a mother would perform (1989:34). Samarasinghe did not find noticeable long-term adverse effects on children's physical and emotional health. In contrast, more recent data suggests a small but significant increase in risk for migrants’ young children (Athauda et al. 2000). Recognizing the need for controlled data, a well-crafted study by Athauda et al. compared the well being of children ages one through five whose mothers were abroad, whose mothers worked 
locally, and whose mothers stayed at home. The study revealed that although over 90 percent of the migrant mothers' children did not suffer behavioral abnormalities, they were roughly three times more likely to develop problems than children whose mothers were at home (Athauda et al. 2000:19). Potential problems included "bed wetting, night walking, clinging to the caretaker, temper tantrums and bad relationship with the siblings" (Athauda et al. 2000:14). For older children, Samarasinghe noted that mothers' migration might have a negative effect on schooling (1989:39). Echoing this, another scholar reports that as they grow older, migrant women’s children tended to drop out of school to join the labor force or look after the household domestic work (Jayaweera et al. 2002:44). One long-term longitudinal investigation suggests that the longer a migrant mother remains away, the greater the problems for the children (Dias and Weerakoon-Gunawardene 1991). Although certainly important, the social costs of migration identified by these researchers differ significantly from the abuse, neglect, addiction, and delinquency featured in media portrayals of migration.

Although children may be better off if their mothers remain in the home, a mother's presence does not automatically eliminate problems for children. As the Athauda et al. study notes, due to pre-existing conditions of poverty (indexed by low birth weight of infants), children of migrant mothers "could be at a disadvantage even before the mothers left them" (Athauda et al. 2000:20). Another author suggests, "The incidence of malnutrition among school children is increasing and about 25 per cent of school children are estimated to be chronically malnourished” (Economist 2004:13). Local economic conditions, including structural adjustment policies implemented in accordance with international dictates, are in part to blame for this situation (Ruwanpura 2000:10). Indeed, the need to provide for daily consumption is one of the main motives for migration, and women's wages often improve a family's nutrition. Discussions 
of the social costs of female labor migration must carefully control for extensive poverty within this segment of the population, and must balance basic needs for food and shelter (which women strive to provide through migration) against the nurturing offered by a mother to her children.

Stories in the popular discourse suggest a connection between female labor migration and male alcohol consumption. In Sri Lanka, most Sinhala and Tamil men drink at least a little (Abeyasinghe 2002). ${ }^{6}$ The Athauda et al. study notes that a child's risk of behavioral problems was increased with the presence of a father who was an alcoholic, drug addict, delinquent, or who did not visit frequently (2000:19). Even moderate drinking can adversely affect a household budget, and alcohol often becomes a bone of contention between husbands and wives, especially when drinking threatens a family's economic well-being (Baklien and Samarasinghe 2003). This sort of conflict can cause stress for children (Seilhamer and Jacob 1990). Marital conflict over male drinking often both precedes and follows female labor migration in Naeaegama. As a quintessentially male signifier, alcohol use can reaffirm a man's masculinity in the face of the gender crisis caused by a woman assuming the breadwinner role and a man taking over domestic duties (Gamburd in press). Female migration and male alcohol use are both prevalent phenomena in Sri Lankan culture, but as the ethnographic data below illustrate, explaining the complex dynamics of their co-occurrence requires moving beyond a simple attribution of cause and effect.

While any harm to children is to be deplored, exaggerating and distorting these incidents and myopically blaming them on migration also has a negative impact. Dramatic rumors of abuse, incest, rape, and drug addiction draw attention away from lived realities of changes in educational and marriage patterns among the children of migrants. In the four case studies that follow, I examine how extended families in Naeaegama have facilitated and adjusted to longterm female labor migration. 


\section{Not even a gold chain for herself: Selfless mothering}

Shriyakanthi was the eldest child in a poor family. Her father abandoned the family when she was young, leaving her mother to raise three children alone. Shriyakanthi married at the age of 14 against her will. She had many troubles with her husband. ${ }^{7}$ When her eldest daughter, Irangani, was five, Shriyakanthi went to the Middle East, leaving her two daughters (and later a young son born after a vacation in Sri Lanka) with her mother. By 2004, Shriyakanthi had worked abroad for eighteen years. Her wages supported her mother, brothers, and children. With what she earned, the family built a house, provided education for the children, bought land for one of her brothers, and gave generous dowries to Shriyakanthi’s two daughters. Villagers unanimously agreed that this family had greatly improved their economic status due to Shriyakanthi's extended migration and her mother's careful use of the money earned abroad.

In March 2004, I visited Shriyakanthi’s eldest daughter. Irangani, age 24, said that when she was young, she and her sister sometimes got mad at their grandmother because they thought that she was telling their mother not to come home. But if their mother had stayed home, the family would have had no food. Irangani knew that her mother went abroad for the sake of the family, which could never have improved its economic situation without her work. But Shriyakanthi's children did not "spend time in her lap" during their childhood. Irangani felt that their mother was never there to "pet” (huuratal keranDa) them, read to them, play with them, or comb their hair; only their grandmother did these things. Irangani was not angry with her mother, but she did feel that she had missed her mother's warmth, love, and nurturing (una suma).

Irangani’s grandmother had taken a great interest in the children’s education. Irangani had passed her A-Level exams, missing the highly competitive university entrance by only a few 
marks. ${ }^{8}$ Since she could not continue her studies, Irangani entered into an arranged marriage and moved in with her husband's family. At the time of our interview, her husband had been working in Italy for nearly a year as a live-in caregiver for an elderly couple. He got his job through an uncle, and he hoped to be able to find Irangani a position as a seamstress in Italy in the near future.

Irangani said that her mother earned money and gave it all to the family. Shriyakanthi had no savings for her own future, "not even a gold chain” (the minimum symbol of financial wellbeing). Like her own mother who had worked so hard for the family’s advancement, Shriyakanthi expected to spend her old age with one of her children. Respecting all the hard work their mother had done, Shriyakanthi's daughters hoped to persuade her not to return to the Middle East when she next came to Sri Lanka. Since Irangani’s father often hit and scolded his wife Shriyakanthi, Irangani felt Shriyakanthi should stay with Irangani instead of getting beaten up (guTi kanawaa, literally “eating fist,”) at home. But both Irangani and her younger sister were planning to go abroad themselves. While abroad, they would not be able to protect their mother, who did not want to live alone with her husband. The girls felt that their grandmother and young brother would not be able to defend their mother adequately. Given this situation, Shriyakanthi's best option was to remain in the Middle East.

At the time of my interview with Irangani, her grandmother was looking after Irangani’s uncles' children while their wives worked in the Middle East. Irangani felt that her cousins were better off than she and her siblings, because they had their fathers around to "pet" them, whereas her own father had often been absent. These children's fathers loved them, and helped the grandmother wash and feed them. Irangani felt that her cousins would not suffer from their mothers' absence because of all the affection they received from their fathers and grandmother. 
As scholars have noted, after children adjust to their mothers' absence, they seem relatively happy (Samarasinghe 1989). In this case, the extended family provided the nurturing necessary to raise the children while the migrants worked abroad to allow the family to build for the future.

This case reveals clear local norms for understanding abandonment and neglect. In Irangani's family, her maternal grandfather was the one who abandoned his family, leaving her grandmother to raise three children alone with no financial support. In contrast, Irangani’s mother sent all of her earnings to the family, keeping nothing for herself. Neither individual spend much time with kin, but only the negligent grandfather was excluded from the extended family. In contrast, Shriyakanthi had accrued a social debt, which her children planned to repay with protection and support. This case illustrates that in Naeaegama, "neglect" is a matter of finance, not face-time.

In this family, an entire generation of women (Shriyakanthi and her sister-in-laws) is away in the Middle East. The grandmother performs the domestic and reproductive labor in the household in exchange for current financial support and expectation of care in her old age. Shriyakanthi continues to work for the family's benefit in hopes of similar care when she gets older. Perhaps in the next generation (Irangani's), things will be different; Irangani and her sister plan to go overseas before having children. This situation mirrors a village-wide shift in the profile of the migrant population, with more people going to Italy, more highly educated people going abroad, and more unmarried women and men entering the migration stream (Wanasundera 2001). The delay of marriage and childbearing (Morrison 2004:34) and the possibility of reuniting entire families, starting businesses, and staying on permanently in Italy (none of which is possible for poor migrant women in the Middle East due to prevalent restrictions) suggest that in the next ten years the situation of many young Sri Lankans may change dramatically. ${ }^{9}$ If entire 
young nuclear families go abroad, more elderly parents and grandparents may find themselves living alone - not the return they had expected for their selfless reproductive labor (WaxlerMorrison 2004:248-9).

\section{My mom wasn't there: A lonely daughter}

Gnanasiri's wife went abroad for six years. With the money that she earned as a domestic servant in the Middle East and the money that Gnanasiri earned as a cinnamon peeler in Sri Lanka, the couple purchased two plots of land and built two houses, one for each of their sons. They also saved money for their daughter's dowry. In a long and wide-ranging interview with the family, I collected diverse stories about migration.

Gnanasiri’s daughter Kanchanamala, 23, said that she was six years old when her mother first went abroad. Before she left, her mother enrolled Kanchanamala in school. She says that she and her younger and older brothers did not suffer much when their mother left because they were living with their maternal grandmother and aunt. The second time their mother went abroad, Kanchanamala was eleven, and her nuclear family had moved to a new house. Their father took care of them, and she and her brothers were very sad (goDak dukkai) because they missed their mother a lot. When Kanchanamala was 13, her mother came home for three months of vacation, and then went abroad again. Shortly before her mother came back from this third trip, Kanchanamala reached puberty, an event celebrated with great splendor in the village (Winslow 1980). Her mother had to renew her expired passport before she could come home. Although the family postponed the puberty ceremony for six weeks, Kanchanamala's mother was not able to attend. 
Kanchanamala suggested that in some migrant families, the father makes poor moneymanagement decisions when the mother is away, causing difficulties for everyone. Her own father, however, did not waste money; instead he peeled cinnamon and supported the family with his earnings. Gnanasiri confirmed this; he claimed that while his wife was away, he rose at four in the morning, cooked, prepared the children for school, and then left for work himself. Gnanasiri felt that the children were fine; he was the one coping with many difficulties.

Later in the interview, when Gnanasiri had gone out, Kanchanamala’s elder brother said that their father drank and sometimes fought with their mother. While their mother was away, their father drank and fought with the neighbors. He was sometimes strong, fierce (sarai) and cruel (napuruwi). But Kanchanamala disagreed with her brother and defended her father, saying that because he was fierce, he brought the children up well. If he was at home, they were very quiet and well behaved. She felt that his fierceness was good for them and kept them out of trouble.

Kanchanamala's mother passed away several years after her permanent return from abroad, soon before Kanchanamala was to take her O-Level exams. Although she took the exam, Kanchanamala had had no time for studying or after-school tutorial classes. She managed to pass her business studies subject. For the other tests, she said she put her head down on the table because she did not know what to write. In this case a migrant's child did not go as far as she could have in her schooling, but the proximate cause of the mother's absence was death, not migration.

I asked Kanchanamala what the happiest time in her life had been. She said that on the days she was expected to be the happiest, such as when she reached puberty or wore her first sari, her mother was not around. Since her mother had passed away, there was no chance of great 
happiness. My research associate asked, “What about when you marry?” Kanchanamala replied, “Well, my mom won’t be here for that either!”

Despite Kanchanamala's grief for her mother, the family seemed prosperous and happy.

Both sons held stable jobs, and Kanchanamala seemed poised to make a good arranged marriage. In addition, Gnanasiri was looking after two of his brothers' children and Kanchanamala was helping them with their studies while their mother worked abroad. In this case one family's successful migration has enabled it to support a relative (and the relative's children) in a similar endeavor.

As both Irangani and Kanchanamala note, children of migrants sometimes yearn for their mothers. Due to their repeated, prolonged absences from their families, mothers often miss both the landmark life-cycle rituals and the everyday events that constitute their children's childhood. At the same time, children understand that their mothers and fathers have pragmatically prioritized the family's needs, focusing on necessities such as food, shelter, education, and dowries. The extended family steps in to provide for children's emotional needs. The adult children of migrants portray the separation of mother and child as a sad but necessary aspect of family advancement.

\section{Living in “Mother's shade”: Concrete manifestations of migrant mothering}

Like Kanchanamala, Piyal was separated from his mother first through migration, then through her death in a motor accident. His mother worked in the Middle East for a total of ten years on five separate contracts. At the time of my interview with Piyal, Piyal's father, estranged earlier from his wife and subsequently from his four sons, lived with another woman in a different village. Both parents were gone, but only one was mourned; the boys had usually sided 
with their mother in frequent disputes with their often-drunken father. In early 2004, three of the four sons had married. Piyal, 24, was unmarried and drove a delivery tractor for the local hardware store. He lived with his brother's family in the house that was bought with the money their mother earned abroad. A large, artistic plaque by the front door proclaimed the residence "Mother's Shade” (mav sevana; shade here means “shelter from sun,” not "ghost”).

Piyal remembered that on their mother's first trip abroad, he and his brothers felt sad and Piyal's youngest brother, age two, came down with heartache (sankaava, loneliness or obsession). Then they all got used to her absence. They were lonely again each time she left after a visit, but soon after things would go back to normal. Each boy and their father wrote a letter every two weeks; "Five sheets would go in one envelope.” They did not write about their problems, but sometimes asked her for toys or money, which she would send. With their mother's money the family bought the house and land, modernized the house and fitted it for electricity, built a well and toilet, purchased a small cinnamon garden, and provided tuition classes for the youngest brother. Their mother also focused determinedly on her youngest son's education after her return from the Middle East.

Piyal felt that overall his mother's migration had been a good idea. The family developed economically, even though the older boys' education suffered some. Their father worked as a hospital attendant, and only their grandfather stayed at home; the boys were not as disciplined as other village children whose mothers or grandmothers were at home. Piyal remembered that he and his brothers would pretend to go to school and then play truant. They went swimming in the river or the ocean, or they went hunting for birds' nests with other boys. If their mother had been at home, Piyal thought they might have attended school more often and gone further in their studies. Nevertheless all four sons held steady jobs, the three eldest took their O-Level exams, 
and the family was reasonably well off due to the mother's hard work. The youngest brother took his A-levels; his education was interrupted not by his mother’s migration but by her death.

In this family, the father and grandfather assumed the domestic duties involved in raising four sons while the father continued to work full time. Despite his father's steady job, Piyal attributed the family's financial success to his mother's work overseas. He and his brothers blamed the marital stress between their parents not on their migrant mother's absence but on their father's drinking habit. In this case, despite many years of financial cooperation between husband and wife, the sons remember their mother's efforts the most vividly.

\section{Housework, not homework: Filling an absent mother's shoes}

Neluka, age 20, was eight months pregnant when we spoke with her at her mother's house in early 2004. Her mother, Winitha, spent seven years abroad. When Winitha first went abroad, her youngest child was a year and a half old, and Neluka, her eldest, was five. With the money she earned abroad, Winitha provided for her family's daily consumption, started a new cement house, and earned money that she gave to her daughters as dowry. Many villagers feel that Winitha's husband, a heavy drinker, did little to help the family develop. The couple fought regularly over alcohol and money.

Boys and girls experience their mother's absences differently. Like Piyal, Neluka felt that her education suffered because her mother was abroad. But while Piyal went swimming and hunted birds' nests, Neluka was helping her grandmother look after her three younger siblings (see Parrenas 2005:109-112). Even though Neluka was quite clever, she could not go to school. Her grandmother was not well, so she and her younger sister and brothers did some of the housework. Neluka studied up to O-Levels but did not take the exam. She thought that if her 
mother had not gone abroad, she could have taken her O-Level exam and used that qualification to get a job in a garment factory, one of the few salaried economic opportunities available to women in Naeaegama.

Neluka and her younger sister married very young, Neluka at 19 and her sister at 15. Both were love marriages. Neluka felt that if her mother had been at home, her younger sister would not have married so early. Neluka herself was in a difficult position, since her husband did not have a steady job and the couple had no permanent place to live. They were staying with Neluka’s parents until the baby was born. As dowry, Winitha gave each daughter a large wardrobe and 25,000 rupees (US\$ 250), but both young couples were in dire financial straits. When I asked Neluka whether she might consider going abroad herself to earn some money for her family, she replied that she would not want what happened to her and her siblings to happen to her own child. Financial necessity may change this position in the future, particularly if Winitha is willing to look after her grandchildren while her daughters work abroad.

The patterns of early marriages and daughters taking over housework chores for absent mothers appeared in other migrant women's families also. As expectations of leisure and the demand for care work in richer countries draw women at the prime of their working life away from home, older women (grandmothers), younger women (school girls), and men take on more domestic duties in Sri Lanka. Although such tasks constitute a violation of childhood in EuroAmerican expectations, they are well within normal expectations in Naeaegama families, even those with resident mothers. Nevertheless, such duties can interfere with a girl's schooling. The promise of higher education or a job can prompt women to delay marriage or defer childbearing, but immersion in the care of the home seems to hasten matrimony, particularly in poor, highstress households. 


\section{Drowning one's sorrows in liquor}

Despite women’s pragmatic prioritizing of their family’s daily needs, suffering ( $d u k k a)$ remains a prevalent theme in popular culture and in Naeaegama discussions of absent mothers and wives. Common discursive elements suggest that poverty prompts migration, which in turn brings about loneliness, heartache, and mixed emotions, as conflicting priorities tear people in

different directions. The words of a popular love song, “Oh, My Little Ones,” index both the pain of a stay-at-home father and the expectation that he will drown his sorrows in liquor:

My little ones are raising their hands to the sky

There's such a big commotion - they say their mother is coming

The land is pawned and there's no way to redeem it

Therefore you set off, my dear. Love is very high interest indeed.

The path where we met was full of golden Asela flowers

We pledged love - you married a bundle of suffering.

The jet plane carrying you is now passing overhead.

Our little ones are weeping because you did not care to disembark.

They refuse to eat - my lumps of rice seem too big.

They refuse to sleep - my lullabies seem to have no rhythm.

I am sleepless too - for my thoughts are with you.

My mind is restless. I need some nectar to sedate myself. 
Song by Asanka Priyamantha Peiris

Translated by Swarna Kanthi Rajapakse

The lyrics use rich symbolism and evocative images to depict the thoughts of a migrant's husband as he looks after his small children and thinks of his absent wife. Let me focus here on the "nectar" referred to at the end of the song, which can represent either a sexual partner or an alcoholic beverage. In Naeaegama, men suggest that if a man's wife goes abroad, he will either pursue other women or take to drink. Local women, however, are skeptical of this logic, noting that many men drink before their wives leave the village and continue to do so after their return. Alcohol is both a comfort to men and a source of conflict with their wives, especially when men drink to excess in families of limited financial means.

Male alcohol consumption patterns raise the question of which comes first: migration, marital discord, or heavy drinking. The available data do not suggest a simple causal arrow leading from female migration to male alcohol abuse as commonly portrayed in the media (Gamburd in press). Instead, scholarly analysis on related cases suggests that poverty and lack of dignified employment can lead some men to drink in excess (Singer 1986; Singer et al. 1998). In Naeaegama, a combination of low-wage local jobs for men and relatively well-paying foreign jobs for women creates a crisis in masculinity for Naeaegama men who cannot fulfill the ideal breadwinner role. Instead, they may assume domestic duties for their migrant wives, a necessary but demeaning undertaking. Alcohol, as a quintessentially masculine beverage, provides an avenue for reaffirming shattered self-esteem. At the same time, expenditure on alcohol drains the family's finances and becomes a source of contention between spouses. Local gender ideals and international employment opportunities intersect in shaping these family dynamics. 
Alcohol use figures in all four case studies above. These cases reveal some correlations in marital harmony, degree of alcohol consumption, and fathers' productive involvement in the family. On one end of the continuum, Gnanasiri and his wife cooperated in a financial strategy that used her wages from the Middle East and his wages from peeling cinnamon to raise the family to a high level of economic stability and social status. Although Piyal's father drank, fought with his wife, and ultimately separated from her, he held a job as a hospital attendant and worked with his wife to purchase land, improve the house, and educate the children. Shriyakanthi's relationship with her drinking husband was so strained that she preferred to remain abroad rather than live with him in Sri Lanka. Although they were still officially married, her husband lived away from the family and provided only a small amount of financial support for his children. In this case, the grandmother made all the decisions about the family's finances; her shrewd planning and frugality raised the family from extreme poverty to an enviable level of success. At the other end of the continuum, Winitha's husband actively fought with his wife over the use of family money. Winitha claimed that her husband's drinking habit consumed everything he earned peeling cinnamon and more besides. She felt that she had achieved a certain standard of living (a half-finished cement house) despite, not because of, her husband's actions.

In these and other families in Naeaegama, increased alcohol consumption correlated with poverty, higher levels of marital tension, and lower levels of financial cooperation between husband and wife. The most successful families were those where the husband and wife agreed on a financial strategy and cooperated in its implementation. Next came families where couples had separated and the husbands lived elsewhere. Families who struggled the hardest financially were those where a wife fought constantly with a heavily drinking husband over the best use of 
household funds. Not coincidentally, the families with the most marital tension and the least financial security were also the families where migrants' children had the lowest levels of education and the earliest ages of marriage.

\section{Conclusion}

In the interviews discussed above, the adult children of migrants revealed much about gender relations, family structures, and kinship obligations, both through what they said and what they did not say about their families' experiences with female migration to the Middle East. As Carla Risseeuw (1991) evocatively notes, “The fish don’t talk about the water”; people take certain situations for granted. The individuals I interviewed all spoke about financial stress, but discussed it as a characteristic of their own households. They did not talk about the water: the context of national and international inequality in which their poverty arose, or why families could not make ends meet despite hard work in the local economy. They recognized the global economy as a solution to financial stress, but not as part of its cause. They also saw men's drinking habits as individual choices or personality flaws, rather than as responses to a wider political economic situation (Singer 2001). Their narratives distorted the role of the Sri Lankan state and the global economy in their discussion of both female migration and male drinking habits.

Changes in gender roles and family obligations reflect the influence of the global economy on local social structures. After a quarter century, labor migration is now firmly embedded in a whole generation's image of motherhood. Interview data reveal that local families conceptualize both nurturing and neglect in terms of providing tangible material benefits such as food and shelter. The choice to leave children behind and work in West Asia is so widely 
accepted that Neluka's stated preference not to go abroad could raise eyebrows, especially if she and her husband are unable to provide for their growing family. Several young adults discussed their relationships with their mothers in material terms; Piyal, for example, mentioned the money and toys that their mothers had sent home. This indicates a commodification of the mother-child relationship, a shift also observed in other migrant communities (Parrenas 2002:50). But despite the widely accepted priority for women to provide financially for their kin, stories abound about migrants abandoning their children, women taking on unnatural roles, and the concomitant risks to families. These discourses echo older gender and kinship ideals while masking the state's abdication of responsibility for the reproduction of the labor force. Transnational migration has clearly affected local concepts of motherhood, though older ideals persist in the face of change.

As relatives do in situations of poverty around the world, kinfolk in Naeaegama take care of children to allow their parents to work. As a child, Kanchanamala was looked after by her grandmother and aunt; as a young adult, she took care of her nephews. Poor women in Sri Lanka have always worked, so women's migration is not unexpected in this regard. But in this most recent and visible manifestation of women's labor, women leave not only the home but also the country, remain abroad for years at a time, and in some cases turn their domestic duties over to their husbands as well as their female kin. This combination challenges gendered dichotomies dear to both locals and scholars, and it puts stress on local men who, home-bound and unemployed, may turn to alcohol to affirm their masculinity. As noted in the media, many migrants' husbands drank, some of them heavily. But so did the husbands of non-migrant women. Although male alcohol use correlates in part with female migration, both phenomena have their roots in local poverty. 
As migration affects gender roles and family relations, local social structures reciprocally influence global dynamics. Over the past quarter century, as women have worked abroad, they have succeeded in some of their goals. Members of the younger generation are better educated and have more financial security than their parents. Some of these children are themselves going abroad, but with a new set of goals and aspirations. In November of 2004, when I returned briefly to Naeaegama, Irangani had joined her husband in Italy, and Piyal had migrated to Kuwait to work as a chauffeur. Irangani and Piyal exemplify the emerging trend away from destinations in West Asia and the growth in male migration. This suggests that the efforts of migrant mothers to improve their children's lives will have an effect on global migration patterns in the future.

Changing migration trajectories and demographic patterns will in turn influence intergenerational kinship obligations. As Sri Lanka's population continues to age in the next two decades, proportionately more elders will need care (Economist 2007). Simultaneously, more migrants are likely to take their nuclear families to Italy with plans to settle. This may, as in Irangani's family, lead to conflicts over the care for the older generation. Kin obligations could again change how individuals make decisions about migration, perhaps in the future limiting rather than facilitating mobility. These dynamics illustrate the ongoing interactions between the smallest and the largest units of human social organizations, the family and the global economy. 


\section{Literature Cited}

Abeyasinghe, Ranil

2002 Illicit Alcohol: Drinking Culture in Colombo - A Study of Alcohol Consumption among the Urban Poor in a South Asian Capital. Colombo: Vijitha Yapa Publications.

Anderson, Bridget

2000 Doing the Dirty Work? The Global Politics of Domestic Labor. London: Zed Books.

Appadurai, Arjun

1990 Disjuncture and Difference in the Global Cultural Economy. Public Culture 2(2):1-24.

Athauda, Thamara, D. Fernando, and A. Nikapotha

2000 Behavioral Problems among the Pre-school Children of Migrant Mothers in Sri Lanka. Journal of the College of Community Physicians of Sri Lanka 5:14-20.

Baklien, Bergljot and Diyanath Samarasinghe

2003 Alcohol and Poverty in Sri Lanka. Dehiwala, Sri Lanka: Norwegian Institute for Urban and Regional Research (NIBR)/ Solidaritetsakjonen for utvikling (FORUT), Sridevi Printers.

Blackwood, Evelyn

2005 Wedding Bell Blues: Marriage, Missing Men, and Matrifocal Follies. American Ethnologist 32(1):3-19.

Central Bank 
2003 Central Bank of Sri Lanka Annual Report 2002. Colombo: Central Bank of Sri Lanka

Chang, Grace

2000 Disposable Domestics: Immigrant Women Workers in the Global Economy. Cambridge, Mass: South End Press.

Cole, Jennifer and Deborah Durham

2007 Generations and Globalization: Youth, Age, and Family in the New World Economy. Bloomington: Indiana University Press.

Collier, Jane and Sylvia Yanagisako

1987 Toward a Unified Analysis of Gender and Kinship. In Gender and Kinship: Essays Toward a Unified Analysis. Jane Collier and Sylvia Yanagisako, eds. Pp. 14-50. Stanford: Stanford University Press.

Constable, Nicole

1997 Maid to Order in Hong Kong: Stories of Filipina Workers. Ithaca: Cornell University Press.

Daily Mirror

2003 GL: Women’s Status in Lankan Society Much Change. Daily Mirror, October 30:

4.

Decena, Carlos Ulises, Michele G. Shedlin, and Angela Martinez 2006 “Los Hombres No Mandan Aqui”: Narrating Immigrant Genders and Sexualities in New York. Social Text 24(3):36-54.

De Munck, Victor C 
1996 Love and Marriage in a Sri Lankan Muslim Community: Toward a Reevaluation of Dravidian Marriage Practices. American Ethnologist 23:698-716.

Dias, Malsiri and Nedra Weerakoon-Gunawardene

1991 Female Labour Migration to Singapore and Hong Kong: A Profile of the Sri Lankan Housemaids. Colombo: Centre for Women's Research (CENWOR).

Economist

200456 Years after Independence: Economy at the Crossroads. Sunday Times, February 8: 13.

2007 Facing Up to the Challenges of an Ageing Population. Sunday Times Online, June 24. Electronic document, http://www.sundaytimes.lk/070624/Columns/eco.html, accessed June 26, 2007.

Eelens F, T. Mook, and T. Schampers

1992 Introduction. In Labor Migration to the Middle East: From Sri Lanka to the Gulf. F. Eelens, T. Schampers, and JD Speckmann, eds. Pp. 1-25. London: Kegan Paul International.

Ehrenreich, Barbara and Arlie Russell Hochschild, eds.

2002 Global Woman: Nannies, Maids, and Sex Workers in the New Economy. New York: Metropolitan.

Freeman, Carla

2001 Is Local: Global as Feminine: Masculine? Rethinking the Gender of Globalization. Signs 26(4):1007-1037.

Hochschild, Arlie and Barbara Ehrenreich 
2002 Introduction. In Global Women: Nannies, Maids, and Sex Workers in the New Economy. Arlie Hochschild and Barbara Ehrenreich, eds. Pp. 1-14. New York: Metropolitan Books.

Gamburd, Michele Ruth

1995 Sri Lanka’s “Army of Housemaids”: Control of Remittances and Gender Transformations. Anthropologica 37:49-88.

1998 Absent Women and Their Extended Families: Sri Lanka’s Migrant Housemaids. In Negotiation and Social Space: A Gendered Analysis of Changing Kin and Security Networks in South Asia and Sub-Saharan Africa. Carla Risseeuw and Kamala Ganesh, eds. Pp. 276-291. New Delhi: Sage.

2000 The Kitchen Spoon's Handle: Transnationalism and Sri Lanka’s Migrant Housemaids. Ithaca: Cornell University Press.

2002 Breadwinner No More: Identities in Flux. In Global Women: Nannies, Maids, and Sex Workers in the New Economy. Arlie Hochschild and Barbara Ehrenreich, eds. Pp. 190-206. New York: Metropolitan Books.

2003 In the Wake of the Gulf War: Assessing Family Spending of Compensation Money in Sri Lanka. International Journal of Population Geography 9(6):503-515. 2005 Lentils There, Lentils Here: Sri Lankan Domestic Labour in the Middle East. In Asian Women as Transnational Domestic Workers. Shirlena Huang, Brenda S.A. Yeoh, and Noor Abdul Rahman, eds. Pp. 92-114. Singapore: Marshall Cavendish. In Press Breaking the Ashes: The Economics and Identity Politics of Illicit Liquor in Sri Lanka. Ithaca: Cornell University Press.

Gunatillake, Godfrey and Myrtle Perera, eds. 
1995 Study of Female Migrant Worker (sic). Colombo: Marga Institute (Sri Lanka Centre for Development Studies), World Bank, and Ministry of Policy Planning and Implementation.

Harrison, Faye V.

1997 The Gendered Politics and Violence of Structural Adjustment. In Situated Lives:

Gender and Culture in Everyday Life. Louise Lamphere, Helena Ragone and Patricia Zavella, eds. Pp. 451-468. New York: Routledge.

Hoskins, Janet

2002 Predatory Voyeurs: Tourists and "Tribal Violence" in Remote Indonesia. American Ethnologist 29(4):797-828.

Institute of Policy Studies

2003 Sri Lanka: State of the Economy. Institute of Policy Studies: Colombo.

Jayaweera, Swarna, Malsiri Dias, and Leelangi Wanasundera

2002 Returnee Migrant Women in Two Locations in Sri Lanka. Colombo: Centre for Women's Research (CENWOR).

Kearney, Michael

1995 The Local and the Global: The Anthropology of Globalization and Transnationalism. Annual Review of Anthropology 24:547-565.

Khalaf, Sulayman N.

1992 Gulf Societies and the Image of Unlimited Good. Dialectical Anthropology 17:53-84.

Khalaf, Sulayman and Saad Alkobaisi 
1999 Migrants' Strategies of Coping and Patterns of Accommodation in the Oil-Rich Gulf Societies: Evidence from the UAE. British Journal of Middle Eastern Studies 26(2):271-298

Kapadia, Karin

1993 Marrying Money: Changing Preference and Practice in Tamil Marriage. Contributions to Indian Sociology 27(1):25-51.

Longva, Anh Nga

1997 Walls Built on Sand: Migration, Exclusion, and Society in Kuwait. Boulder: Westview Press.

Lutz, Catherine A. and Lila Abu-Lughod, eds.

1990 Language and the politics of emotion. Cambridge: Cambridge University Press. Lynch, Caitrin

1999 The 'Good Girls’ of Sri Lankan Modernity: Moral Orders of Nationalism and Capitalism. Identities: Global Studies in Culture and Power 6:55-89.

2002 The Politics of White Women's Underwear in Sri Lanka’s Open Economy. Social Politics: International Studies in Gender, State, and Society 9(1):87-125

2007 Juki Girls, Good Girls: Gender and Cultural Politics in Sri Lanka’s Global Garment Industry. Ithaca: Cornell University Press.

Magazine, Roger and Martha Areli Ramirez Sanchez

2007 Continuity and Change in San Pedro Tlalcuapan, Mexico: Childhood, Social Reproduction, and Transnational Migration. In Generations and Globalization: Youth, Age, and Family in the New World Economy. Jennifer Cole and Deborah Durham, eds. Pp. 52-73. Bloomington: Indiana University Press. 
Morokvasic, Mirjana, Umut Erel, and Kyoko Shinozaki, eds.

2003 Crossing Borders and Shifting Boundaries, Vol. 1: Gender on the Move. Opladen, Germany: Leske \& Budrich.

Morrison, Barrie M.

2004 Overwhelming Change and Faltering Institutions, 1948-2002. In Sri Lankan

Society in an Era of Globalization: Struggling to Create a New Social Order. S.H.

Hasbullah and Barrie M. Morrison, eds. Pp. 25-56. New Delhi: Sage Publications.

Nagy, Sharon

1998 This Time I Think I'll Try a Filipina: Global and Local Influences on Relations Between Household Workers and Their Employers. City and Society 10(1):83104.

Nakkavita and Jayamanne

2004 A Pension Scheme Would Be Useful To Migrant Workers. The Island, January 10: 10 .

Nicholson, Melanie

2006 Without Their Children: Rethinking Motherhood Among Transnational Migrant Women. Social Text 24(3): 13-33.

Ong, Aihwa

1999 Flexible Citizenship: The Cultural Logics of Transnationality. Durham: Duke University Press.

Ortner, Sherry B.

2006 Anthropology and Social Theory: Culture, Power, and the Acting Subject. Durham: Duke University Press. 


\section{Parrenas, Rhacel Salazar}

2001 Servants of Globalization: Women, Migration, and Domestic Work. Stanford: Stanford University Press.

2002 The Care Crisis in the Philippines: Children and Transnational Families in the New Global Economy. In Global Woman: Nannies, Maids, and Sex Workers in the New Economy. Barbara Ehrenreich and Arlie Russell Hochschild, eds. Pp. 39-

54. New York: Metropolitan.

2005 Children of Global Migration: Transnational Families and Gendered Woes. Stanford, CA: Stanford University Press.

Phillips, Lynne

2006 Food and Globalization. Annual Review of Anthropology 35: 37-57.

Rakesh, K. M.

2007 Lanka Bans Mothers From Overseas Jobs. The Gulf Today, March 9.

Risseeuw, Carla

1991 Gender Transformation, Power and Resistance Among Women in Sri Lanka: The Fish Don't Talk About the Water. New Delhi: Manohar

Ross, Ellen

1995 Review: New Thoughts on “The Oldest Vocation”: Mothers and Motherhood in Recent Feminist Scholarship. Signs 20(2):397-413.

Ruwanpura, Kanchana N.

2000 Structural Adjustment, Gender and Employment: The Sri Lankan Experience. Geneva: ILO.

Samarasinghe, Gameela 
1989 The Psycho-Social Implications of Middle East Migration on the Family Left Behind. Colombo: Centre for Women's Research (CENWOR).

Scheper-Hughes, Nancy

1992 Death Without Weeping: The Violence of Everyday Life in Brazil. Berkeley: University of California Press.

Seilhamer, Ruth Ann and Theodore Jacob

1990 Family Factors and Adjustment of Children of Alcoholics. In Children of Alcoholics: Critical Perspectives. Michael Windle and John S. Searles, eds. Pp. 168-186. New York: The Guilford Press.

Singer, Merrill

1986 Toward a Political-Economy of Alcoholism: The Missing Link in the Anthropology of Drinking. Social Science and Medicine 23(2):113-130.

2001 Toward a Bio-Cultural and Political Economic Integration of Alcohol, Tobacco and Drug Studies in the Coming Century. Social Science and Medicine 53:199213.

Singer, Merrill, Freddie Valentin, Hans Baer, and Zhongke Jia 1998 Why Does Juan Garcia Have a Drinking Problem? The Perspective of Critical Medical Anthropology. In Understanding and Applying Medical Anthropology. Peter J. Brown, ed. Pp. 286-302. Mountain View: Mayfield Publishing Co.

Sri Lankan Bureau of Foreign Employment (SLBFE)

2006 Statistical Handbook on Migration, 2003. Colombo, Sri Lanka: Research Division, SLBFE.

Sri Lanka Department of Census and Statistics 
2004 Education: Performance of Candidates - GCE (O/L), GCE (A/L) and Admissions to Universities. Source: Department of Examinations and University Grants Commission. Electronic document, http://www.statistics.gov.lk/education/performance.pdf, accessed September 27, 2004.

Stacey, Judith

1990 Brave New Families. London: Basic Books.

1997 The Neo-Family-Values Campaign. In The Gender / Sexuality Reader: Culture, History, Political Economy. Roger Lancaster and Micaela di Leonardo, eds. Pp. 453-470. New York: Routledge.

Stack, Carol B.

1970 All Our Kin: Strategies for Survival in a Black Community. New York: Harper and Row.

Trawick, Margaret

1990 Notes on Love in a Tamil Family. Berkeley: University of California Press. Wanasundera, Leelangi

2001 Migrant Women Domestic Workers: Cyprus, Greece and Italy. Colombo: Centre for Women's Research (CENWOR).

Waxler-Morrison, Nancy

2004 Who Will Care for Those Left at Home? The Effect of New Opportunities for Work on Families in Sri Lanka. In Sri Lankan Society in an Era of Globalization: Struggling to Create a New Social Order. S.H. Hasbullah and Barrie M. Morrison, eds. Pp. 241-253. New Delhi: Sage Publications. 
Weerakoon, Nedra

1998 Sri Lanka: A Caste Study of International Female Labour Migration. In Legal Protection for Asian Women Migrant Workers: Strategies for Action. S. Sta. Maria Amparita, J. J. Balisnono, R. Plaetevoet, and R. Selwyn, eds. Pp. 97-118. Makati City, Philippines: Ateneo Human Rights Center.

Weismantel, Mary

1995 Making Kin: Kinship Theory and Zumbagua Adoptions. American Ethnologist 22(4):685-704.

Willis, K.D, and Brenda S.A. Yeoh

2000 Gender and Transnational Household Strategies: Singaporean Migration to China. Regional Studies 34:253-64.

Winslow, Deborah

1980 Rituals of First Menstruation in Sri Lanka. Man, New Series 15(4):603-625. Wright, Melissa W.

2001 The Dialectics of Still Life: Murder, Women, and Maquiladoras. In Millennial Capitalism and the Culture of Neoliberalism. Jean Comaroff and John L. Comaroff, eds. Pp. 125-146. Durham: Duke University Press. 


\section{Acknowledgements}

This paper was originally crafted for the Western Conference of the Association for Asian Studies meetings held in Seattle, Washington in 2004. I would like to thank my fellow panelists and our discussant for their helpful suggestions. I then presented a version of the paper at a conference on "Economic Globalization and Its Implications for Democracy in South Asia” at the University of Texas at Austin in 2005, and another version the same year at the Netherlands Institute for Advanced Study in the Humanities and Social Sciences in Wassenaar, the Netherlands, at a conference entitled “Gender, Ethnicity and Identity: The 'New Maids' in the Age of Globalization.” I also received insightful feedback on a revised version of this paper to the Women’s Studies Program at the University of Pittsburgh in 2007. As I shaped the manuscript for publication in this volume, Sharon Nagy and Andrew Gardner made trenchant and helpful comments, as did three anonymous reviewers from City and Society. I am grateful to all my readers and audiences for their questions and advice. I am solely responsible for any remaining flaws. 
${ }^{1}$ In this essay, I use "West Asia,” "the Gulf,” "the Gulf Cooperation Council (GCC),” and "the Middle East” interchangeably to refer to a varied and diverse region with many cultural traditions. This rich complexity gets lost in many Sri Lankan accounts of migration, where migrants are said to work in “Arabia," "the Middle East,” or merely "abroad.”

2 "Naeaegama” is a pseudonym meaning "village of relatives.” This place name and the names of individuals I interviewed have been changed to preserve the privacy of my informants.

${ }^{3}$ In Sri Lanka, domestic servants are often referred to as "housemaids" in both English and Sinhala. These migrant women's duties often exceed the narrow technical limits of the term.

${ }^{4}$ Transnational labor migration also has profound effects on families in labor-receiving countries. In the United States, the European Union, Hong Kong, Singapore, and Taiwan, migrant domestic servants from developing world regions fill a "care deficit," freeing their female employers from household duties and allowing them to enter the local labor market (Anderson 2000; Constable 1997; Hochschild and Ehrenreich 2002: 8; Parrenas 2002). In many Gulf nations, housemaids free their employers for lives of leisure instead (Longva 1997). In both types of cases, employing domestic servants indexes a family’s affluence, marking their class status and national prestige.

${ }^{5}$ For a compelling in-depth discussion of this topic, see Parennas’s work on the Philippines (2005).

${ }^{6}$ Religious affiliation affects drinking practices; Muslim men drink much less than Sinhala and Tamil men.

${ }^{7}$ Although many women experience marital discord and some separate from their husbands, very few officially divorce. Legal marriage protects the reputations of wives and children; divorce carries grave social stigma.

${ }^{8}$ Sri Lanka uses a British education system. O-level exams follow the eleventh year of education, and A-level exams follow the thirteenth. Less than half of the students sitting for O-Level exams qualify to go to A-Level studies. Only 15-17\% of A-Level students qualified to go on to university have marks high enough to secure one of the coveted places (Sri Lanka Department of Census and Statistics 2004).

${ }^{9}$ In the Gulf Cooperation Council countries, strict regulations on length of stay, difficult-to-meet criteria for bringing in family members, the sponsorship system, inability to own land and businesses, and the nearimpossibility of obtaining citizenship all work to keep guest workers' stays short, temporary, or informal, and to minimize their ability to organize (Khalaf 1992: 72). Various circumstances lead to the insecurity of migrant 
workers in the Gulf, including the rampant discrimination, the dependence on the whims of their sponsor, visa regulations that make staying in the country while changing jobs difficult, the absence of legal rights, and the absence of unions (Khalaf and Alkobaisi 1999: 294). 